\title{
Collaborative Research and Development Management as Strategy for Industrial Growth and Development
}

\author{
Oladele Jaiyesimi Kayode Ogundele \\ Department of Marketing, Lagos State University \\ Ojo- Lagos State, Nigeria \\ Tel: +234-1-805-541-5293_E-mail: oladeleogundele @yahoo.com \\ Olufemi Olabode Olayemi (Corresponding author) \\ Department of Business Administration, University of Lagos \\ Lagos State, Nigeria \\ Tel: +234-1-802-370-5627_E-mail: femolayemi1@yahoo.com \\ Patrick Sunday Okonji \\ Department of Business Administration, University of Lagos \\ Lagos State, Nigeria \\ Tel: +234-1-803-578-9583 \\ E-mail: patforward2000@yahoo.com
}

Received: August 20,2011 Accepted: December 23, $2011 \quad$ Published: April 15, 2012
doi: 10.5430/jms.v3n2p33

\begin{abstract}
This paper focused on Research and development as the foundation for any technological, social and economic development. The gaps between varying levels of development in advanced and developed countries can be explained by the amount of investments made in Research and Development. The components of Research and development were explained in this paper as critical to national development. An integrated model of Research and development was presented and ways of implementing the model explained. This paper calls for a shift in African governments' focus to investments in Technological and other research and development projects for the development of the continent in order to be effectively relevant in the 21st century. Based on vision 2020proposed by Nigerian government, Nigeria is used as a model in fashioning out the required collaborative efforts to put in place a well designed research and Development Corporation that will be a channel for effective implementation of the research and development management.
\end{abstract}

Keywords: Research and Development, Socio Economic, Strategy, Effective Implementation, Industrial Growth

\section{Introduction}

Research is the systematic investigation of using scientific methods for the purpose of either discovering new knowledge or discovering new ways of putting the knowledge into practical use. When it is research for discovering knowledge it is called basic, on the other hand, research for converting knowledge into practice is referred to as applied. Development takes off from the findings of applied research in order to build up or develop products, processes, techniques and service for society consumption. Research and development management therefore refers, conceptually to the set of activities and behaviors' characterizing basic and applied "Research" as well as "Development" activities; when these activities are executed in an organizational setting, and managed to derive new products, new processes, new technologies and new services in commercial quantities for the benefit of society (Ekop-Ufot, 1990).

Strategy refers to a comprehensive series of long-range decision plans, designed to achieve mission, conceived goals and objectives through some creative and clever options of resources allocations and utilization policies, to yield advantages over other options, and over others pursuing similar objectives, or to advice improvement over one's current position (Ekpo-Ufot, 1990 and Adeleke, Ogundele and Oyenuga, 2003). The results of most advances in technological 
development emanate from applied researche. Research in itself is not sufficient, until its outcomes are put in to practical use.

Although, most developing economies realized the growing importance of Research and Development (R\&D) in the industrialization process, sufficient efforts are not be made to actualize this feat. It should be noted that developing economy must see R \& D as a strategic tool to enhance rapid growth and economic development otherwise it will remain at the background. Nigerian government efforts is been appraised to determine the extent to which her growth could be ascertain through R\&D. There would be no meaningful economic development without proper attention given to $R \& D$ and the earlier; that efforts are being geared towards this direction the better for the country.

It has been noted that so many developing nations do not even have capacity and resources to conduct record broken researches not alone put its findings into practical use due to certain factors. This paper seek to address issues that often impede the application of $R \& D$ in most developing economies with emphasizes on the past efforts of Nigerian government and what need to be done in order to encourage and foster the growth of these nations through R\& D activities.

\section{Conceptual Framework}

There is no gain saying the fact that there is a direct link between a nation progress in science and technology and its economic progress. Today, a nation's power and prosperity are largely determined by the scale of its research. (Pans, 1988) Thus the ability to encourage the growth and development and the adaptation of the results of scientific research is a "sine quo non for national economic development". According to Thomas (2004), research is the process of obtaining and analyzing data in order to answer questions solve problems or test hypotheses and so contribute to our understanding and knowledge of the world.

The basic characteristics of research are;

1) It is empirical as it involves the study of the world outside

2) It adopts systematic and explicit methods, it is essentially a public Endeavour in which it is possible, in principle for others to repeat investigations and check on their accuracy.

3) It is a complex craft that is messy and uncertain in nature as opposed to the popular notion of precise results obtained by means of controlled experimentation using sophisticated techniques and technologies. To this end the practice of research may involve its adaptation to local circumstances calling for consideration ingenuity and methodological improvisation.

4) Research study is unique borne out of the fact that research is custom- built enterprises requiring consideration skill and judgment in the design and execution.

According to Pans (1988) there are three types of research; pure research which is a long-term undertaking unrelated to any immediate practical problems but design to improve our knowledge of science and the law of nature. Directed research is a long-term research which has been channeled into specific directions and is aimed at the solution of practical problems. While applied research, the direct servant of technology is designed to improve existing products and manufacturing processes or to develop new ones in extreme cases merges into industrial production.

The economically developed nations of the world, and especially Japan, carried out research and development management which set them apart from other nations. Ekpo-Ufot (1990) in his study of Japanese organizations brings out the set of activities which define research and development ( $R \& D$ ) management. There were four categories of behaviour identified by him. These are:

(1) The purposes or goals of R and D Management: Ekpo-Ufot (1990) notes that eleven goal areas were identified ranging from seeking to discover new knowledge to discovering what technologies other countries have, which they do not yet have and which many be useful for copying.

(2) Idea Contributions for R and D Activities: The second category of behaviour relates to idea contribution for R and D activities by different types of organization members including not only the engineers who largely staffed the R and D departments but also ordinary rank and file members. The ordinary Japanese employee is a graduate of at least the equivalent of our General Certificate of Education (Advanced Level.)

(3) Stages in R and D Activities: These include: (i) basic research (ii) applied research (iii) exploratory development (iv) advanced development or basic invention (v) engineering design specifications (vi) tooling and manufacturing facilities (vii) manufacturing start up for commercialization and (viii) marketing start up. The Japanese conception of research 
and development starts with the pursuit of basic scientific knowledge and ending with the marketing of a useful product (or services). The thrust of this integrated $\mathrm{R}$ and $\mathrm{D}$ activity is for developing indigenous technology.

(4) The Criteria used in Selecting Projects: Two criteria frequently cited were "return on capital investment and pay back period. Immediate profit was not paramount; what mattered was their long-term consideration of the technological impacts of these investments. The excellent position the Japanese now occupy is partly the fruits of their long-term value orientation. This could be any other country's lesson. One predicts that an adequate/effective and efficient R. and D management practices will lead to high organizational productivity. An approach based on a model which is an experiment that will ensure technological development founded on collaborative processes is presented in this study.

\subsection{Research and Development $(R \& D)$ Management as Strategy for National Industrial Development}

The model for the approach suggested in this paper as vehicle for national industrial development based on research and development management strategy is shown in Figure 1. In Figure 1, the primary goal is to develop science and technology graduates, as well as every citizen to be technologically competent. To achieve this, the school and manufacturing organizations in the country have important roles to play.

In Figure 1, the principal institutions of development are the schools and factories. In the model, they are sandwiched together by the double-headed arrows. Ascending arrows in the school system depict academic career growth whereas descending ones emphasize the role of the higher institutions to provide instructions to the lower levels. The sandwiched institutions give students at all levels, opportunities to match their classroom learning with practical work experience in industry. Workers in the industry will, also continue their school learning part time. This will eliminate unemployment. It will also ensure that learning and research are made relevant to the development needs of this country.

Bello- Osagie (2007) discussed initiative of the British Council at facilitating collaborations between tertiary institutions and companies in Nigeria, modeled after the Knowledge Transfer Partnership Programme in the United Kingdom. The programme is tagged African Knowledge Transfer Partnership (AKTP). The implementation of the project is expected to aid business growth with technology inputs from the academia.

Figure 1 is the modified version of a proposal by Ekpo-Ufot (1990), reported by Ogundele and Ojodu (2003) concerning developing indigenous technology in Nigeria. The operations of the experiment depicted in the model are through the Ministries of Education and Science and Technology.

The Ministry of Science and Technology has the most important responsibility to discharge. These are in planning and executing the experiment. The operators are:

(1) The school system

(2) Existing business sector of the economy. They will contribute fund to the national $\mathrm{R}$ and $\mathrm{D}$, which must be compulsory.

(3) National, State and Local governments will also contribute. This will be used to establish R and D corporation, with three major division, instructional and scientific equipment, and motor vehicle and food processing.

(4) Home markets and sub-regional markets are large enough in each case.

(5) The Nigeria 6-3-3-4 and now 9-3-4 education system' cannot afford to depend on import of scientific apparatus. A factory must be established for these at all costs.

(6) We have had assembly plants in this country for over thirty years, there should be a large pull of technicians to drawn from

(7) There are enough local raw materials for the food processing and a good base for developing indigenous technology (Ogundele, 2005). The various agricultural development programmes will all provide large pool of technicians to draw from.

(8) The 6-3-3-4 and now 9-3-4 national education in Nigeria with all its defects, for example had been producing graduates to be recruited into the corporation.

(9) Our Iron and Steel and Chemical Industries should be grown to provide materials for the specialized industries.

The lesson that we have learnt from the West is that $\mathrm{R}$ and $\mathrm{D}$ management is the only sure path to technological development. Equally the East in terms of Soviet Union, Japan and currently China has confirmed the effectiveness of this path. Japan most importantly has shown the centrality of collaborative R and D management and its ability to produce major changes within a decade. The $\mathrm{R}$ and $\mathrm{D}$ Corporation, therefore, should borrow a leave from the Japanese and Chinese practices. The corporations, the governments (National, State, Local) the science and technology school 
systems, and the business sector, all come together to form the corporation. The responsibilities of the Ministry of Science and Technology in this respect are:

(1) Research and identify pools of indigenous scientists, engineers, educationists, technicians etc. and craftsmen from which recruits will be drawn to man the corporation.

(2) Commission feasibility studies for establishing the three projects listed on model 1 and, produce five year plan for the industries.

(3) Get operators to negotiate how to implement, monitor, control and evaluate the projects.

(4) Recruit high-level management staff for the corporation

(5) In cooperation with management staffs recruit other staff needed.

(6) Launch the corporation, sit back, watch and monitor and contribute in the evaluation process.

Ekpo-Ufot (1990) reported ( $\mathrm{R}$ and D) practice in studied Nigerian firms. He had proposed collaborative model of industrial and technological innovation in Nigeria. Therefore the school and factory concept in the model is not new. The "work-study" concept is also not new. There is no doubt that R and D is a necessary condition for technological development. There are various institutions of higher learning in Nigeria. There are also researches and development agencies for example; Project Development Agency (PRODA) had developed over 42 items- machines, equipment and products. However, information on the "market-start-up" stage of R and D is lacking. Ekpiwhre (2008) lamented that PRODA had failed to advance the country technologically. This is due to obsolete machines and attitudinal problems. This situation must change. The $\mathrm{R}$ and $\mathrm{D}$ Corporation must mop up the existing resources and rework them under one roof to complete the $\mathrm{R}$ and $\mathrm{D}$ activity in commercialization.

The idea of specialization is not new. It is here being suggested that Nigeria should specialize in instructional and scientific equipment, food processing and motor vehicle, using these as takeoff. The nation will be borrowing old ideas from outcomes of Japanese-specialization in electronics. All that is contained in the adapted model is to reinforce what others have said. The experiment is a proposal to match words with action. Further comment on the 6-3-3-4 now 9-3-4 education systems in Nigeria are necessary. The Government says this will prepare Nigerians for technological take off. But when will the government match words with deeds, by equipping adequately the laboratories, workshops and other facilities needed for effective implementation of this scheme? This is why the author also advocates the R and D Corporation to include producing instructional and scientific equipment. In the case of motor vehicle, Owolabi (2008) reports that the National Automotive Council (NAC) claimed that, it is using a multi-pronged approach in developing the Nigerian vehicle. One of them is being promoted by Nigerian engineers and investors in the United States which is entirely a private initiative and one that is likely to attract commercial interest, as reported by the writer. The one being advocated have called for collaborative effort of schools, government and the business community on a larger and broader scale.

\section{Conclusion}

This is a call on the Ministry of Education in conjunction with the Ministry of Science and Technology to ensure that in the running of the 6-3-3-4- now 9-3-4 education system, workshops, laboratories; Pilot plants, equipment's tools etc must be adequately supplied from indigenous sources to maintain the system. The implementation of the proposals must be to ensure that deviation from course are corrected and set target met. There is hope for the Blackman, especially since science and technology have become open knowledge. If the pre-requisite conditions that are highlighted in this paper are followed, $\mathrm{R}$ and $\mathrm{D}$ management will accelerate the acquisition of science and technology as programs for achieving sustainable development in Nigeria. It will equally lead to economic self-reliance, if the development of indigenous technology is strongly advocated as a better alternative to technology transfer. To attain this, all stakeholders must involve in cooperative and collaborative actions, which may invariably lead to an entrepreneurial economy if local technology is adequately encourage and developed.

\section{Recommendations}

Nigeria as a developing country has great hopes of joining the most developed nations if only she can harness the potentials of its array of gifted personnel to develop her indigenous technology. To achieve this, the following were recommended:

(1) There should be emphasis on self-reliance as a practice in all our educational levels,

(2) There should be practical emphasis on pure science and science related specialization areas in our secondary and tertiary educational institutions. 
(3) The government should spearhead the suggested collaborative effort between the three parties.

(4) Specific time framework should be set for Nigeria to be self-sufficient in the areas of basic needs.

(5) The government should give more support to indigenous organizations that are in the forefront of Research and Development.

(6) Creation of an enabling environment by the government to promote the development of needed equipment and products.

(7) Encourage the development and implementation of several proposals that are suggested in this paper.

(8) Make sure that compensation for scientists and science related specialization areas are equal if not higher than business and social science related specialization areas. The present government is emphasizing science and technology and this is a good step in the right direction.

(9) The ideal educational system should encourage learners to use their hands and brains, to encourage and boost involvement in vocational education as pointed out by Ojerinde (2008).

The Nigerian government has severally advocated for local contents and for this to be realised, full, there is an urgent need to re appraise the activities of various research institutes to ensure that they are not being used as drain pipes. The effect of huge sum of funds often allocated to Research Institutes has not fully achieve attain the purposeand so, where need be, government should strategically redirect their objectives. Research efforts should equally be intensified in all these institutes and their findings put to more practical use. Government should establish more of these institutes to promote local scientists that believed in our indigenous technology as evident in the production of local herbs (medicinal) that are now been exported in large volumes. This will invariably transmute to creation of more jobs to our teeming unemployed youths and foreign earnings may result from such activities, thereby leading to better 1 recognition at the international level

\section{References}

Adeleke, A. Ogundele, O. J. K. and Oyenuga, O. O. (2003). Business Policy and Strategy; Lagos, Concept Publications.

Bello Osagie, K. (2007). British Council facilitates projects between tertiary institutions, companies The Nation, Thursday November 15, vol. 2. No 0473 p 31.

Ekpiwhre, G. (2008). PRODA has failed says Minister, The Nation, Friday, February 29, Vol. 3. No 0579 pp. 39.

Ekpo- Ufot, A. (1990). Research and development management; A strategy for developing indigenous technology for self-reliance. Discussion Paper, Monthly Technical Seminar Series. Federal Ministry of Science and Technology, 9 Kofo Abayomi Street, Lagos.

Ogundele, O. J. K. (2005). Partnership for developing indigenous technology for economic self reliance, Proceedings of International Conference in Engineering 2005, University of Lagos, 23 - 26 May. 528 - 537.

Ogundele, O. J. K. and Alaka, N. S. (2005). Developing indigenous technology for economic rehabilitation and self-reliance, Multidisciplinary. Journal of Research Development Vol. 5, no. 7, 1-8.

Ogundele, O. J. K. and Ojodu, H. O. (2003). Technology transfer, technological development and New Partnership for Africa's Development (NEPAD) Business Education Focus: A Journal of Business Education and Management, Vol. 4. No.1, pp. $171-188$.

Ojerinde, D. (2008). JAMB's boss votes for vocational education, The Nation Thursday February 29, No 3, vol. 0578, p 17.

Owolabi, M. (2008). We are using a multi - pronge approach in developing the Nigerian vehicle, The Nation, Friday, April 4, No 3, Vol. 0614, p 18.

Pans, A., (1998). Research management in Cetron M and Goldhar Y (eds) The science of managing organized technology, Vol. 1 \& 2 New York; Gordon \& Breach.

Thomas, A. B. (2004). Research skill for management students. London; Routledge 


\section{The Federal Government Ministry of Education Ministry of Science And technology}
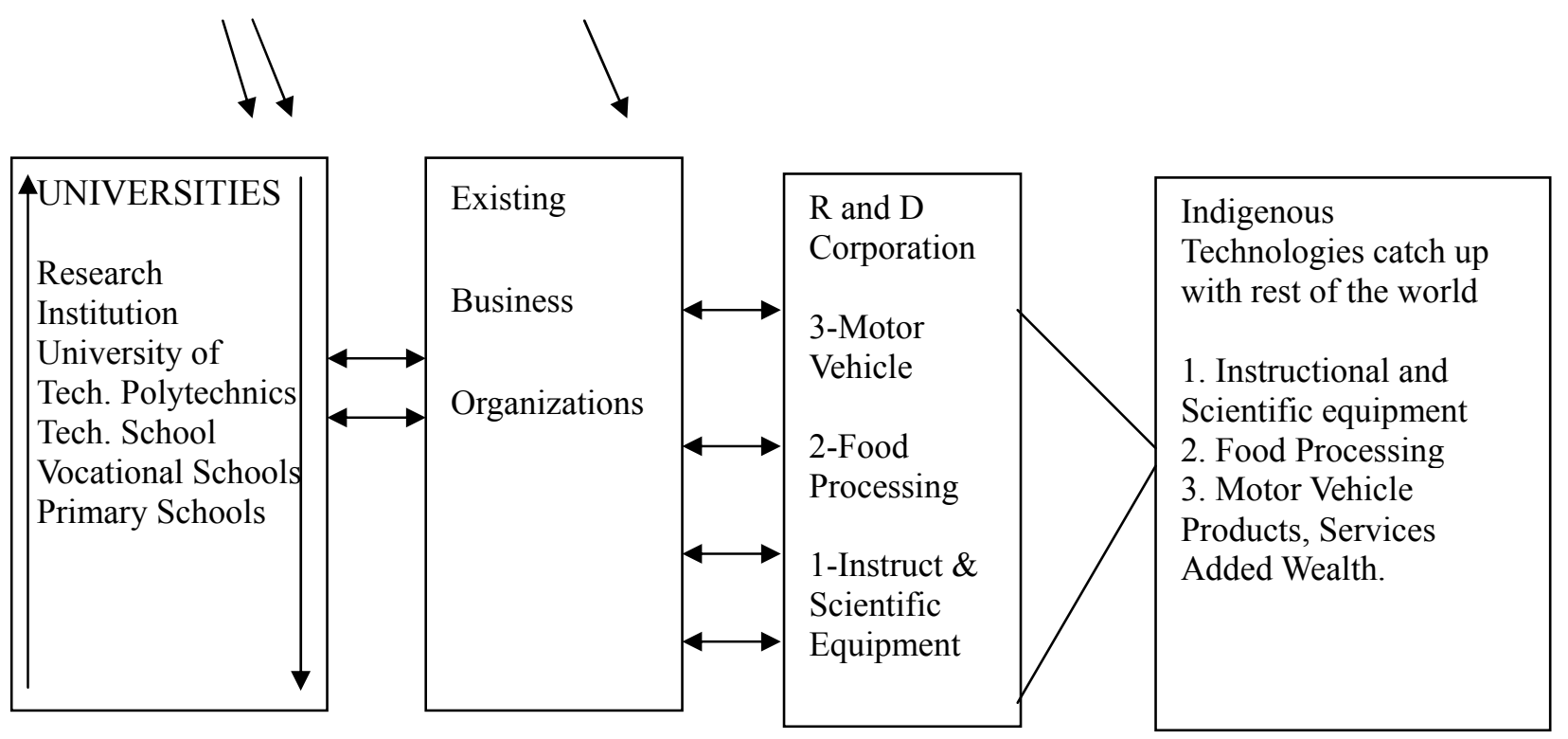

Figure 1. The R \& D Corporation Experiment Model

Source: Adopted from Ekpo-Ufot (1990): Research and Development Strategy, cited in Ogundele 0. J. K. \& Ojodu H. (2003) 